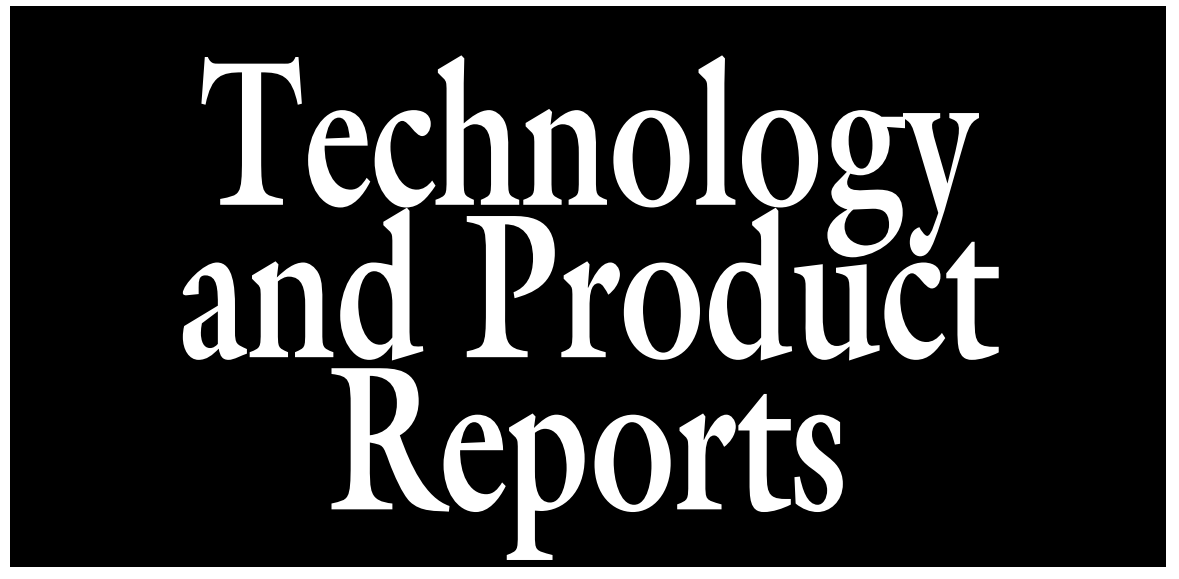

\section{Comparison of Diquat, Glufosinate, and Saflufenacil for Desiccation of 'Dark Red Norland' Potato}

\author{
J. Harrison Ferebee IV ${ }^{1}$, Charles W. Cahoon ${ }^{2}$, \\ Michael L. Flessner ${ }^{3}$, David B. Langston ${ }^{4}$, Ramon Arancibia ${ }^{5}$, \\ Thomas E. Hines ${ }^{1}$, Hunter B. Blake ${ }^{1}$, and M. Carter Askew ${ }^{1}$
}

ADDITIONAL INDEX WORDs. mechanical harvest, preharvest conditioning, skin set, Solanum tuberosum, tuber size

Summary. Chemical desiccants are commonly used to regulate tuber size, strengthen skin, and facilitate harvest for potato (Solanum tuberosum) production. Glufosinate is labeled for potato vine desiccation; however, limited data are available. Saflufenacil, a protoporphyrinogen oxidase-inhibiting herbicide, is an effective desiccant in other crops. Field research was conducted to evaluate glufosinate and saflufenacil as desiccants applied to 'Dark Red Norland' potato. Desiccants consisted of diquat, glufosinate, saflufenacil, glufosinate plus carfentrazone, and glufosinate plus saflufenacil applied at three timings, DESIC-1, DESIC-2, and DESIC-3, when size B potatoes averaged $43 \%, 31 \%$, and $17 \%$ of total potato weight. Potato vine desiccation was more difficult at DESIC- 1 and DESIC- 2 because of immature vines. Diquat was the most effective desiccant 7 days after treatment (DAT), desiccating potato vines $88 \%$ at DESIC-1 7 DAT. Glufosinate alone desiccated potato vines $65 \%$ at the same timing; however, carfentrazone and saflufenacil added to glufosinate increased vine desiccation $8 \%$ and $16 \%$ compared with glufosinate alone, respectively. Vine desiccation by all treatments ranged $99 \%$ to $100 \%$ at 14 DAT. Desiccant and timing effects on skin set were determined using a torque meter before harvest. Skin set resulting from all desiccants and timings ranged between 1.88 and $2 \mathrm{lb}$-inch, and no significant differences were observed. No significant differences in yield were noted among desiccants. This research indicates that glufosinate and saflufenacil are suitable alternatives to diquat for potato vine desiccation; however, safety of saflufenacil applied to potatoes before harvest has not been determined.

$\mathrm{P}$ otato acreage in the United States during 2018 totaled $1,023,300$ acres, producing $454,314,000 \mathrm{cwt}$ of potatoes [U.S. Department of Agriculture (USDA), 2018]. Red potato production represented $7 \%$ of the total U.S. potato production (Richardson, 2017). Potato cultivar Red Norland is produced more than any other type of red facilitate more efficient harvest due to reduced vegetation. Vine desiccation may be executed via mechanical destruction or chemical desiccation (Boydston et al., 2018; Murphy, 1968). However, chemical desiccation is the preferred method to regulate tuber size and skin strength (Kuhar et al., 2018; Murphy, 1968). Vine desiccation timing is based on tuber size at desiccation and desired potato grade at harvest (Boydston et al., 2018). Furthermore, effective vine desiccation depends on vine maturity: mature vines are easier to desiccate than immature vines (Haderlie et al., 1989). Potato size, determined by diameter or weight, receives designations from smallest to largest of Creamer, B, A, and Chef potatoes (USDA, 2011). Producers of red-skinned potatoes rely on vine desiccation to regulate tuber size with the overall goal to maximize B potato yield, which has the greatest economic value of all potato grades (Richardson, 2017; Strange and Blackmore, 1990; USDA, 2011).

Skin set is the physiological process that occurs during the end of periderm maturation when tuber growth has ceased (Lulai and Orr, 1993; Nolte and Olsen, 2005). The periderm, or skin, prevents moisture loss and degradation by diseases and other pests (Nolte and Olsen, 2005). In comparison with the periderm of the 'Russet Burbank' potato, the periderm of many potato cultivars, including Red Norland, matures much slower (Lulai and Orr, 1993). Sabba and Bussan (2012) evaluated the skin set of the 'Red Norland' potato across multiple soil types and found no consistent relationship between skin set and soil type. However, relative humidity $(\mathrm{RH})$ has been demonstrated to influence skin set. Postharvest skin set evaluations of the 'Norchip' and 'Norland' potato at $50 \%$ and $95 \% \mathrm{RH}$ (and constant temperature) demonstrated that a phenotypic increase in skin set could only be achieved at $50 \%$ RH (Lulai and Orr, 1993). Time between vine desiccation and harvest also influences skin set. In a Washington study, 'Bintje' and 'Ciklamen' potatoes harvested 2 weeks after vine desiccation incurred $55 \%$ skinning injury compared with $5.1 \%$ when harvest was delayed 4 weeks (Boydston et al., 2018).

Sulfuric acid is the most effective potato vine desiccant when compared with dinoseb, diquat, endothall, 
glufosinate, and pyraflufen-ethyl; however, sulfuric acid is a highly corrosive substance that requires specialized equipment and extreme precaution (Boydston et al., 2018; Haderlie et al., 1989). Before 1986, dinoseb, a dinitrophenol compound, accounted for $70 \%$ of the herbicides used for potato vine desiccation because of its effectiveness when applied in warm weather (Haderlie et al., 1989; Murphy, 1968; Mutch et al., 1984). After dinoseb was removed from the market for health concerns in 1986, diquat became the standard potato vine desiccant (Haderlie et al., 1989; Pavlista, 2001). Previous research reports diquat and dinoseb desiccated potato vines $80 \%$ and $85 \%$ at 2 weeks after treatment (WAT), respectively (Haderlie et al., 1989).

Diquat, a member of the bypyridylium herbicide family, is a Weed Science Society of America group 22 photosystem I electron diverter that is used as a desiccant in potato, oilseeds, and legumes [Fabaceae (Syngenta, 2015)]. Diquat can result in incomplete stem and leaf desiccation, generally a result of incomplete spray coverage, which can result in tuber

Received for publication 21 Feb. 2019. Accepted for publication 20 May 2019.

Published online 7 August 2019.

${ }^{1}$ School of Plant and Environmental Sciences, Virginia Tech, Eastern Shore Agriculture Research and Experiment Station, 33446 Research Drive, Painter, VA 23420

${ }^{2}$ Department of Crop and Soil Sciences, North Carolina State University, Campus Box 7620, Raleigh, NC 27695

${ }^{3}$ School of Plant and Environmental Sciences, Virginia Tech, 675 Old Glade Road, Blacksburg, VA 24060

${ }^{4}$ Tidewater Agriculture Research and Extension Center, School of Plant and Environmental Sciences, Virginia Tech, Tidewater Agricultural Research and Extension Center, 6321 Holland Road, Suffolk, VA 23437

${ }^{5}$ University of Missouri, 1 N Delaware Street, Butler, MO 64730

Funding for this work was provided in part by the Virginia Agricultural Experiment Station and the Hatch Program of the National Institute of Food and Agriculture, U.S. Department of Agriculture. This research was partially funded by the Virginia Potato Board.

J.H.F., T.E.H., H.B.B., and M.C.A. are Graduate Research Assistants.

C.W.C. and M.L.F. are Assistant Professors.

D.B.L. is a Professor and Director.

R.A. is a Field Specialist.

C.W.C. is the corresponding author. E-mail: cwcahoon@ ncsu.edu.

This is an open access article distributed under the CC BY-NC-ND license (https://creativecommons.org/ licenses/by-nc-nd/4.0/).

https://doi.org/10.21273/HORTTECH04327-19 regrowth (Boydston et al., 2018; Misener and Everett, 1981; Pavlista, 2001). Diquat should never be applied to drought stressed potatoes, and if a second application is required, a 5 -d waiting period between applications is recommended for improved vine coverage (Kuhar et al., 2018; Syngenta, 2015). Paraquat, also a member of the bypyridylium family of herbicides, has been shown to effectively desiccate potato vines; however, paraquat facilitates potato deterioration during storage and, therefore, is rarely used (University of Maine, 2011).

Alternatives to diquat for vine desiccation include glufosinate, carfentrazone, and pyraflufen-ethyl (Kuhar et al., 2018). As a potato vine desiccant, harvest is legally required to be delayed at least $9 \mathrm{~d}$ following glufosinate application. Research comparing potato vine desiccation by glufosinate and diquat indicated glufosinate was not as effective as diquat at 3 and $7 \mathrm{~d}$ after treatment (Ivany and Sanderson, 2001). However, at 14 DAT, vine desiccation by glufosinate was similar to that by diquat (Boydston et al., 2018). In another study comparing potato vine desiccants, glufosinate, diquat, sulfuric acid, carfentrazone, and pyraflufenethyl were evaluated. Glufosinate plus pyraflufen-ethyl more effectively desiccated potato vines than glufosinate alone. Harvest two WAT resulted in similar tuber skinning injury among all treatments except glufosinate, which significantly reduced skinning injury. However, it is important to note that glufosinate treatments were applied several days before all other desiccants to account for slower vine death (Boydston et al., 2018). Glufosinate applied as a desiccant also resulted in a $6 \%$ increase in potatoes with a diameter of $35-70 \mathrm{~mm}$, which is categorized as a B potato. Glufosinate consequently reduced the number of potatoes $>70 \mathrm{~mm}$, which are categorized as $\mathrm{A}$ potatoes and hold less economic value (Gonnella et al., 2009; USDA, 2011).

Carfentrazone-ethyl and saflufenacil are both group 14 protoporphyrinogen oxidase (PPO)-inhibiting herbicides (BASF, 2016; FMC Corp., 2015). Carfentrazone is labeled for potato vine desiccation and requires complete coverage of the targeted plant to ensure successful desiccation (FMC Corp., 2015). Limited data exist for carfentrazone used as a potato vine desiccant (Kuhar et al., 2018). Saflufenacil is used as a harvest aid in cotton (Gossypium hirsutum), oilseeds, and small grains and can be applied as a single application or sequential applications (BASF, 2016). Saflufenacil evaluated as a potential harvest aid in edible bean desiccated leaf, pod, and stem $87 \%, 80 \%$, and $62 \%$, respectively, and desiccation was similar to or greater than that by carfentrazone, diquat, and glufosinate 8 DAT (Soltani, 2013). Although saflufenacil is not currently labeled for potato vine desiccation and no published research exists, saflufencacil's history as a harvest aid has peaked interest in using the herbicide for potato vine desiccation.

Although alternatives to diquat exist for potato vine desiccation, research on these alternatives is limited. The primary objective of this research was to compare potato vine desiccation by diquat with that by glufosinate and saflufenacil. The secondary objective was to evaluate the relationship between desiccant and timing and their collective effects on yield, grade, and skin set of red-skinned potato.

\section{Materials and methods}

Experiments were conducted at the Eastern Shore Agricultural Research

\begin{tabular}{llll}
\hline $\begin{array}{l}\text { Units } \\
\begin{array}{l}\text { To convert U.S. to SI, } \\
\text { multiply by }\end{array}\end{array}$ & U.S. unit & SI unit & $\begin{array}{l}\text { To convert SI to U.S., } \\
\text { multiply by }\end{array}$ \\
\hline 0.4047 & acre $(\mathrm{s})$ & $\mathrm{ha}$ & 2.4711 \\
45.3592 & $\mathrm{cwt}$ & $\mathrm{kg}$ & 0.0220 \\
112.0851 & $\mathrm{cwt} / \mathrm{acre}$ & $\mathrm{kg} \cdot \mathrm{ha}^{-1}$ & 0.0089 \\
0.3048 & $\mathrm{ft}$ & $\mathrm{m}$ & 3.2808 \\
9.3540 & gal/acre & $\mathrm{L} \cdot \mathrm{ha}^{-1}$ & 0.1069 \\
2.54 & inch(es) & $\mathrm{cm}$ & 0.3937 \\
25.4 & inch(es) & $\mathrm{mm}$ & 0.0394 \\
11.2985 & lb-inch $(\mathrm{es})$ & $\mathrm{N} \cdot \mathrm{cm}^{1}$ & 0.0885 \\
1.1983 & lb/l00 gal & $\mathrm{g} \cdot \mathrm{L}^{-1}$ & 0.8345 \\
1.1209 & lb/acre & $\mathrm{kg} \cdot \mathrm{ha}^{-1}$ & 0.8922 \\
70.0532 & oz/acre & $\mathrm{g} \cdot \mathrm{ha}^{-1}$ & 0.0143
\end{tabular}


and Extension Center near Painter, VA (lat. $37.58939^{\circ} \mathrm{N}$, long. $75.82375^{\circ} \mathrm{W}$ ) during 2017 and 2018 . The soil type for both years included a Bojac sandy loam (coarse loamy, mixed, semiactive, thermic Typic Hapludults) with $1 \%$ organic matter and $\mathrm{pH} 6.4$.

In both years, potato cultivar Dark Red Norland was planted into fields prepared with one pass by a moldboard plow followed by a disc harrow followed by a field cultivator. Potatoes were planted on 13 Mar. 2017 and 30 Mar. 2018 on adjacent fields for a total of two site-years. The experimental design was a randomized complete block with treatments replicated three times. Plots consisted of two rows by $30 \mathrm{ft}$, with rows spaced $3 \mathrm{ft}$ apart. Two border rows were used to separate plots and limit physical drift of desiccants from plot to plot.

Treatments consisted of a factorial arrangement of three vine desiccation timings by five herbicide treatments. Vine desiccation timings were initiated when percent $B$ potatoes (pound B potatoes/pound total potatoes $\times$ $100)$ averaged 43\% (DESIC-1), 31\% (DESIC-2), or 17\% (DESIC-3). Herbicide treatments consisted of diquat, glufosinate, saflufenacil, glufosinate plus carfentrazone, glufosinate plus saflufenacil, and no herbicide. Adjuvants co-applied with desiccants included nonionic surfactant $(0.25 \% \mathrm{v} /$ $\mathrm{v})$, ammonium sulfate [AMS (15 lb/ 100 gal spray solution)], methylated seed oil [MSO $(1 \% \mathrm{v} / \mathrm{v})]$ plus AMS (8.5 lb/100 gal spray solution), AMS (15 lb/100 gal spray solution), and MSO (1\% v/v) plus AMS (15 lb/100 gal spray solution) with diquat, glufosinate, saflufenacil, glufosinate plus carfentrazone, and glufosinate plus saflufenacil, respectively. All plots received paraquat $(0.75 \mathrm{lb} /$ acre $)$ plus $S$-metolachlor $(0.98 \mathrm{lb} /$ acre $)$ plus metribuzin $(0.33 \mathrm{lb} / \mathrm{acre})$ following dragoff on 5 and 23 Apr. during 2017 and 2018, respectively. Herbicide desiccation applications were made on 1,8 , and 15 June 2017 and 7, 14, and 21 June 2018. Herbicide application rates and sources for all herbicides are listed in Table 1. All herbicides were applied using a propane-pressurized backpack sprayer equipped with flat-fan nozzles (XRl1003 extended-range flat spray nozzles; TeeJet Technologies, Wheaton, IL) delivering $20 \mathrm{gal} /$ acre at 24 psi.

Visible estimates of potato stem and leaf desiccation were evaluated on a $0 \%$ to $100 \%$ scale (Haderlie et al., 1989) and collected at 4, 7, and 14 DAT. Before harvest, potatoes from each plot were collected for a skin set evaluation. Evaluations were conducted via a torque meter equipped with 100-grit aluminum oxide sandpaper measuring tuber skin set in pound per inch. Plots were mechanically harvested at the conclusion of the season to determine potato yield. Following harvest, potatoes were graded into size categories: Chef, $\mathrm{A}$, and $\mathrm{B}$ (USDA, 2011). To determine total yield, Chef, A, and B potatoes from each plot were combined.

Data for vine desiccation, tuber skin set, and potato yield were subjected to analysis of variance using the Fit Model procedure in JMP Pro
13 software (SAS Institute, Cary, NC). Desiccation timing, desiccant treatment, and site-year were considered fixed effects, whereas replications were treated as random. Treatment means were separated using Fisher's protected least significant difference $[$ LSD $(P=0.05)]$, when appropriate.

\section{Results and discussion}

All data satisfied the normality assumption and did not require transformation. The three-way interactions of year by desiccant by desiccation timing were not significant for any parameter recorded. Likewise, the two-way interactions of year by desiccant and year by desiccation timing were not significant for any parameter recorded. However, the two-way interaction of desiccant by desiccation timing was significant for potato stem desiccation. Therefore, data for potato stem desiccation are presented by timing, whereas potato leaf desiccation, skin set, and yield were pooled across year and desiccation timing and presented by desiccant. Means for desiccation timing were included for potato leaf desiccation, skin set, and yield.

Potato stem desiccation. Potato stem desiccation was more difficult earlier in the season at DESIC-1 and DESIC- 2 when Size B potatoes averaged $43 \%$ and $31 \%$, respectively, compared with DESIC-3 when Size B potatoes averaged $17 \%$ (Table 2 ). At the first two desiccation timings, 4 DAT, diquat was generally more effective than glufosinate alone and

Table 1. Herbicides and adjuvants used for potato vine desiccation experiments in Painter, VA, in 2017 and 2018.

\begin{tabular}{|c|c|c|c|c|}
\hline $\begin{array}{l}\text { Herbicides and } \\
\text { adjuvants }^{z}\end{array}$ & Trade names & $\begin{array}{l}\text { Application } \\
\text { time }^{\mathrm{y}}\end{array}$ & $\begin{array}{l}\text { Application } \\
\text { rate }^{\mathrm{x}}\end{array}$ & Manufacturer \\
\hline Diquat & Reglone $^{\circledR}$ & POST & $0.5 \mathrm{lb} /$ acre & $\begin{array}{l}\text { Syngenta Crop Protection, } \\
\text { Greensboro, NC }\end{array}$ \\
\hline Nonionic surfactant & Scanner $^{\circledR}$ & POST & $0.25 \% \mathrm{v} / \mathrm{v}$ & $\begin{array}{l}\text { Loveland Products, Inc., Greeley, } \\
\text { CO }\end{array}$ \\
\hline $\begin{array}{l}\text { Glufosinate } \\
\text { ammonium }\end{array}$ & Rely $^{\circledR} 280$ & POST & $0.38 \mathrm{lb} / \mathrm{acre}$ & $\begin{array}{l}\text { Bayer CropScience, Research } \\
\text { Triangle Park, NC }\end{array}$ \\
\hline Saflufenacil & Sharpen ${ }^{\circledR}$ & POST & $\begin{array}{l}0.71,0.36 \mathrm{oz} / \\
\text { acre }\end{array}$ & $\begin{array}{l}\text { BASF Chemical Co., Research } \\
\text { Triangle Park, NC }\end{array}$ \\
\hline Methylated seed oil & $\mathrm{MSO}^{\circledR}$ concentrate with Leci-Tech $^{\circledR}$ & POST & $1 \% \mathrm{v} / \mathrm{v}$ & Loveland Products, Inc. \\
\hline Carfentrazone & $\operatorname{Aim}^{\circledR} \mathrm{EC}$ & POST & $0.8 \mathrm{oz} / \mathrm{acre}$ & FMC Corp., Philadelphia, PA \\
\hline
\end{tabular}


Table 2. Potato stem desiccation as influenced by desiccant and timing in Painter, VA. Data for 2017 and 2018 are pooled.

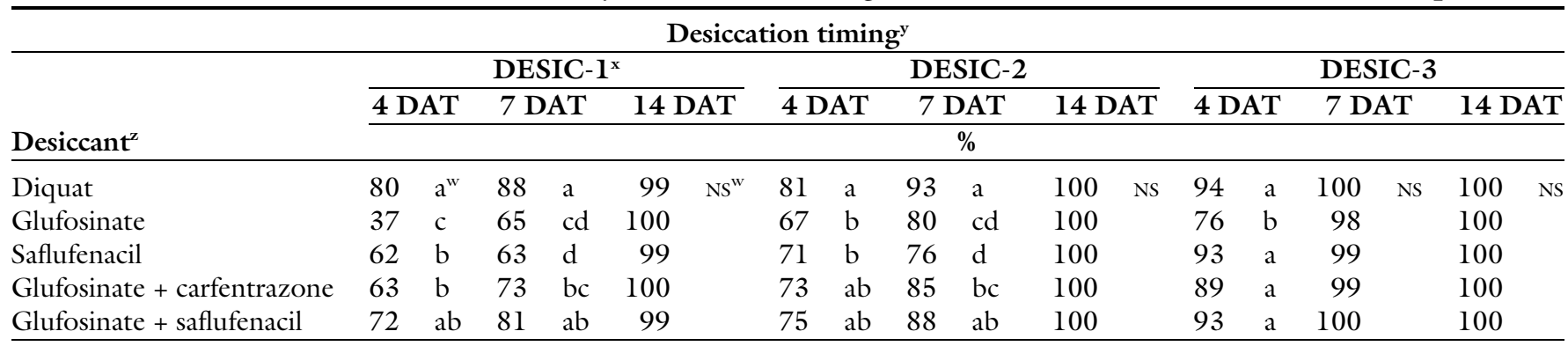

${ }^{\mathrm{z}}$ Diquat, glufosinate, and carfentrazone were applied at $0.5 \mathrm{lb} / \mathrm{acre}, 0.38 \mathrm{lb} / \mathrm{acre}$, and $0.8 \mathrm{oz} /$ acre, respectively. Saflufenacil was applied at $0.7 \mathrm{loz} / \mathrm{acre}$ alone and $0.36 \mathrm{oz} /$ acre when mixed with glufosinate; $1 \mathrm{lb} / \mathrm{acre}=1.1209 \mathrm{~kg} \cdot \mathrm{ha}^{-1}$ and $\mathrm{l} \mathrm{oz} / \mathrm{acre}=70.0532 \mathrm{~g} \cdot \mathrm{ha}^{-1}$.

${ }^{y}$ Size B potatoes averaged $43 \%, 31 \%$, and $17 \%$ at DESIC-1, DESIC-2, and DESIC-3, respectively (USDA, 2011).

${ }^{\times}$DESIC- $1=$ first vine desiccation timing, DESIC- $2=$ second vine desiccation timing, DESIC- $3=$ third vine desiccation timing, DAT $=$ days after treatment.

"Means within a column followed by the same letter are not different according to Fisher's protected LSD test at $P=0.05$; NS $=$ not significant.

Table 3. Potato leaf desiccation averaged over desiccation timing as influenced by desiccant in Painter, VA. Data for 2017 and 2018 are pooled.

\begin{tabular}{|c|c|c|c|c|c|c|}
\hline \multirow[b]{2}{*}{ Desiccant $^{\mathrm{z}}$} & \multicolumn{2}{|c|}{$4 \mathrm{DAT}^{\mathrm{y}}$} & \multicolumn{2}{|c|}{7 DAT } & \multicolumn{2}{|c|}{$14 \mathrm{DAT}$} \\
\hline & \multicolumn{6}{|c|}{$\%$} \\
\hline Diquat & 96 & $\mathrm{NS}^{\mathrm{w}}$ & 99 & NS & 100 & NS \\
\hline Glufosinate & 94 & & 99 & & 100 & \\
\hline Saflufenacil & 93 & & 96 & & 100 & \\
\hline Glufosinate + carfentrazone & 95 & & 99 & & 100 & \\
\hline Glufosinate + saflufenacil & 96 & & 99 & & 100 & \\
\hline \multicolumn{7}{|l|}{ Dessicant timing ${ }^{\mathrm{x}}$} \\
\hline DESIC-1 & 93 & $b^{w}$ & 95 & $\mathrm{~b}$ & 100 & NS \\
\hline DESIC-2 & 91 & $\mathrm{~b}$ & 99 & $\mathrm{a}$ & 100 & \\
\hline DESIC-3 & 100 & $\mathrm{a}$ & 100 & $\mathrm{a}$ & 100 & \\
\hline
\end{tabular}

Table 4. Potato skin set averaged over desiccation timing as influenced by desiccant in Painter, VA. Data for 2017 and 2018 are pooled.

\begin{tabular}{|c|c|c|}
\hline \multirow{3}{*}{$\frac{\text { Desiccant }^{\mathrm{z}}}{\text { Diquat }}$} & \multirow{2}{*}{\multicolumn{2}{|c|}{$\frac{\text { Skin set }}{\text { lb-inch }^{\mathrm{y}}}$}} \\
\hline & & \\
\hline & 1.98 & NS ${ }^{x}$ \\
\hline Glufosinate & 1.91 & \\
\hline Saflufenacil & 2 & \\
\hline Glufosinate + carfentrazone & 1.88 & \\
\hline Glufosinate + saflufenacil & 1.98 & \\
\hline No desiccant & 1.92 & \\
\hline \multicolumn{3}{|l|}{ Dessicant timing ${ }^{w}$} \\
\hline DESIC-1 & 1.96 & NS \\
\hline DESIC-2 & 1.99 & \\
\hline DESIC-3 & 1.9 & \\
\hline
\end{tabular}

${ }^{\mathrm{z}}$ Diquat, glufosinate, and carfentrazone were applied at $0.5 \mathrm{lb} /$ acre, $0.38 \mathrm{lb} /$ acre, and $0.8 \mathrm{oz} /$ acre, respectively. Saflufenacil was applied at $0.71 \mathrm{oz} /$ acre alone and $0.36 \mathrm{oz} /$ acre when mixed with glufosinate; $\mathrm{l} \mathrm{lb} /$ acre $=1.1209 \mathrm{~kg} \cdot \mathrm{ha}^{-1}$ and $\mathrm{l} \mathrm{oz} / \mathrm{acre}=70.0532$ $\mathrm{g} \cdot \mathrm{ha}^{-1}$.

${ }^{y} 1 \mathrm{lb}$-inch $=11.2985 \mathrm{~N} \cdot \mathrm{cm}^{-1}$.

${ }^{\mathrm{x}} \mathrm{NS}=$ not significant.

${ }^{\mathrm{w}}$ Size B potatoes averaged $43 \%, 31 \%$, and $17 \%$ at DESIC-1, DESIC-2, and DESIC-3, respectively (USDA, 2011); DESIC-1 = first vine desiccation timing, DESIC-2 = second vine desiccation timing, DESIC- 3 = third vine desiccation timing. saflufenacil alone. Diquat works much faster than glufosinate; therefore, observation soon after application often favors diquat (Ivany and Sanderson, 2001; Soltani, 2013), as was the case for this experiment. Diquat applied at DESIC-1 and DESIC-2 desiccated potato stems $80 \%$ and $81 \%$ at 4 DAT, respectively; potato stem desiccation by glufosinate alone and saflufenacil alone was $<71 \%$. A similar trend was observed 7 DAT at which diquat remained more effective than glufosinate or saflufenacil. Potato stem desiccation by diquat applied at DESIC-1 and DESIC-2 desiccated potato stems $88 \%$ to $93 \%$ at 7 DAT. Activity of glufosinate alone and saflufenacil alone 7 DAT was no better than $80 \%$. However, by $14 \mathrm{~d}$ after DESIC- 1 and DESIC-2 potato stem desiccation by all treatments ranged $99 \%$ to $100 \%$. Later in the season, diquat applied at DESIC-3 continued to be more effective than glufosinate 4 DAT. However, potato stem desiccation by diquat and saflufenacil at this time was similar. Moreover, 7 and $14 \mathrm{~d}$ after DESIC-3, all treatments similarly desiccated potato stems $98 \%$ to $100 \%$. Immature vines result in slower desiccation than mature vines that have begun to naturally deteriorate (Haderlie et al., 1989), which may explain treatment similarities later in the season when potato vines were more mature.

In general, saflufenacil plus MSO improved initial potato stem desiccation by glufosinate. Glufosinate applied at DESIC-1 desiccated potato stems $37 \%$ and $65 \%$ at 4 and 7 DAT, respectively. At this same timing, saflufenacil added to glufosinate increased stem desiccation $35 \%$ at 4 DAT and $16 \%$ at 7 DAT. Similarly, glufosinate plus saflufenacil was more effective than glufosinate $7 \mathrm{~d}$ after DESIC- 2 and $4 \mathrm{~d}$ after DESIC- 3 . It should be noted that glufosinate plus saflufenacil was equally effective as diquat at all rating intervals when applied at DESIC-1, DESIC-2, or DESIC-3. Similar to saflufenacil, carfentrazone added to glufosinate improved initial potato stem desiccation by glufosinate alone, especially $4 \mathrm{~d}$ after DESIC- 1 and DESIC-3.

Potato leaf Desiccation. Potato leaf desiccation was more uniform and complete than stem desiccation across timings and desiccants, similar to findings by Pavlista (2001). Furthermore, leaf desiccation efficacy was not as dependent on vine maturity. Leaf desiccation by all treatments ranged $93 \%$ to $96 \%$ at 4 DAT (Table 3). Similarly, at 7 and 14 DAT, all desiccants desiccated potato leaves $96 \%$ or greater. Averaged across treatments 4 DAT, desiccation was significantly greater when desiccants were 
Table 5. Potato yield and grade in response to desiccant averaged across desiccation timing in Painter, VA. Data for 2017 and 2018 are pooled.

\begin{tabular}{|c|c|c|c|c|c|c|c|c|}
\hline \multirow[b]{2}{*}{ Desiccant $^{\mathrm{z}}$} & \multicolumn{2}{|c|}{ Chef $^{y}$} & \multicolumn{2}{|c|}{ Size A } & \multicolumn{2}{|c|}{ Size B } & \multicolumn{2}{|c|}{ Total } \\
\hline & \multicolumn{8}{|c|}{ cwt/acre ${ }^{x}$} \\
\hline Diquat & 1.1 & $\mathrm{NS}^{\mathrm{w}}$ & 159.53 & NS & 68.94 & NS & 221.13 & NS \\
\hline Glufosinate & 1.5 & & 154.01 & & 62.48 & & 211.45 & \\
\hline Saflufenacil & 2.37 & & 165.44 & & 62.07 & & 221.85 & \\
\hline Glufosinate + carfentrazone & 1 & & 163.01 & & 62.34 & & 217.55 & \\
\hline Glufosinate + saflufenacil & 1.69 & & 161.03 & & 60.65 & & 215.38 & \\
\hline No desiccant & 2.69 & & 175.31 & & 65.2 & & 243.21 & \\
\hline \multicolumn{9}{|l|}{ Dessicant timing $^{\mathrm{v}}$} \\
\hline DESIC-1 & 0.38 & b & 122.75 & $\mathrm{~b}$ & 60.23 & NS & 188.51 & b \\
\hline DESIC-2 & 1.67 & $\mathrm{a}$ & 162.64 & $\mathrm{a}$ & 63.76 & & 228.07 & a \\
\hline DESIC-3 & 2.49 & $\mathrm{a}$ & 171.03 & $\mathrm{a}$ & 65.38 & & 233.76 & $\mathrm{a}$ \\
\hline
\end{tabular}

${ }_{\mathrm{z}}$ Diquat, glufosinate, and carfentrazone were applied at $0.5 \mathrm{lb} / \mathrm{acre}, 0.38 \mathrm{lb} / \mathrm{acre}$, and $0.8 \mathrm{oz} /$ acre, respectively. Saflufenacil was applied at $0.71 \mathrm{oz} /$ acre alone and $0.36 \mathrm{oz} /$ acre when mixed with glufosinate; $1 \mathrm{lb} / \mathrm{acre}=1.1209$ $\mathrm{kg} \cdot \mathrm{ha}^{-1}$ and $\mathrm{l} \mathrm{oz} /$ acre $=70.0532 \mathrm{~g} \cdot \mathrm{ha}^{-1}$.

${ }^{y}$ Potatoes were graded according to USDA standards for potato grades (USDA, 2011).

${ }^{\mathrm{x}} \mathrm{l} \mathrm{cwt} / \mathrm{acre}=112.085 \mathrm{l} \mathrm{kg} \cdot \mathrm{ha}^{-1}$.

${ }^{\text {w}}$ Means within a column followed by the same letter are not different according to Fisher's protected LSD test at $P=0.05 ;$ Ns $=$ not significant.

'Size B potatoes averaged $43 \%, 31 \%$, and $17 \%$ at DESIC-1, DESIC-2, and DESIC-3, respectively (USDA, 2011); DESIC- 1 = first vine desiccation timing, DESIC- 2 = second vine desiccation timing, DESIC- $3=$ third vine desiccation timing.

Table 6. Percent Chef, Size A, and Size B potato grades of total yield in response to desiccant averaged across desiccation timing in Painter, VA. Data for 2017 and 2018 are pooled.

\begin{tabular}{|c|c|c|c|c|c|c|}
\hline \multirow[b]{2}{*}{ Desiccant $^{\mathrm{z}}$} & \multicolumn{2}{|c|}{ Chef $^{y}$} & \multicolumn{2}{|c|}{ Size A } & \multicolumn{2}{|c|}{ Size B } \\
\hline & \multicolumn{6}{|c|}{$\%$} \\
\hline Diquat & 0.4 & $\mathrm{NS}^{\mathrm{x}}$ & 66.6 & NS & 33.1 & NS \\
\hline Glufosinate & 0.5 & & 67.9 & & 31.6 & \\
\hline Saflufenacil & 0.9 & & 69.7 & & 29.4 & \\
\hline Glufosinate + carfentrazone & 0.3 & & 69.1 & & 30.5 & \\
\hline Glufosinate + saflufenacil & 0.7 & & 69.3 & & 30.1 & \\
\hline No desiccant & 0.9 & & 70.7 & & 28.4 & \\
\hline
\end{tabular}

${ }^{\mathrm{z}}$ Diquat, glufosinate, and carfentrazone were applied at $0.5 \mathrm{lb} / \mathrm{acre}, 0.38 \mathrm{lb} / \mathrm{acre}$, and $0.8 \mathrm{oz} / \mathrm{acre}$, respectively. Saflufenacil was applied at $0.71 \mathrm{oz} /$ acre alone and $0.36 \mathrm{oz} /$ acre when mixed with glufosinate; $1 \mathrm{lb} / \mathrm{acre}=1.1209$ $\mathrm{kg} \cdot \mathrm{ha}^{-1}$ and $\mathrm{loz} / \mathrm{acre}=70.0532 \mathrm{~g} \cdot \mathrm{ha}^{-1}$.

${ }^{\mathrm{y}}$ Potatoes were graded according to USDA standards for potato grades (USDA, 2011).

${ }^{x} \mathrm{NS}=$ not significant.

applied: DESIC-3 compared with DESIC-1 and DESIC-2. Furthermore, 7 DAT, desiccants applied DESIC-2 and DESIC-3 were slightly more effective than desiccants applied DESIC-1. All treatments and timings resulted in $100 \%$ potato leaf desiccation 14 DAT.

SKIN SET. Similar to results for leaf desiccation, no differences in skin set were noted among desiccant treatments (Table 4). Skin set for all desiccants ranged 1.88 to $2 \mathrm{lb}$-inch. In addition, averaged over desiccant treatments, values for skin set were similar across all desiccation timings. Adequate rainfall resulted in appropriate soil moisture before and after vine desiccation to allow for effective skin set. About $60 \%$ soil moisture at vine desiccation is required for adequate skin set (Nolte and Olsen,
2005). At least $18 \mathrm{~d}$ separated vine desiccation and harvest, which is sufficient time for effective skin set. At shorter harvest intervals, differences in skin set may be observed (Boydston et al., 2018; Nolte and Olsen, 2005). The extended harvest delay may also explain why the nontreated control yielded similar skin set to treated plots, as the vines were able to naturally senesce (Haderlie et al., 1989).

YIELD. Although potato yield and grade for all desiccant treatments were statistically similar (Table 5 ), numerical trends were evident, especially between plots receiving a desiccant and plots not receiving a desiccant. In the absence of a desiccant, potatoes tended to be larger. Chef and Size A potato in nontreated plots were 2.69 and 175.31 cwt/acre, respectively, compared with 1 to $2.37 \mathrm{cwt} / \mathrm{acre}$ for Chef and 154.01 to $165.44 \mathrm{cwt} /$ acre for Size A in treated plots. Across treatments, Chef and Size A potato were significantly reduced when desiccants were applied DESICl compared with DESIC-2 and DESIC-3. Although not statistically significant, percentage of Chef potatoes in nontreated plots was greater than that in all desiccant treatments, except saflufenacil (Table 6). Similarly, percent Size A potatoes in nontreated plots was $\approx 71 \%$ compared with $67 \%$ to $69 \%$ in treated plots. Despite treatment differences between Chef and Size A potatoes, little differences were observed when comparing desiccants for Size B yield. Size B potatoes hold the greatest value among potato grades (Richardson, 2017). Gonnella et al. (2009) found that environmental conditions have a much greater impact on potato yield than desiccants. Rainfall for April, May, and June totaled 6,22 , and $6 \mathrm{~cm}$, respectively, in 2017 and 5,13 , and $12 \mathrm{~cm}$, respectively, in 2018. Overall, rainfall was adequate for the growing season, and neither year experienced absence of rainfall $>10 \mathrm{~d}$. This may explain why differences in potato yield and grade were minimal. However, it should be noted that despite differences in yield and grade, desiccants can facilitate harvest and skin set when the harvest interval is short (Murphy, 1968).

Diquat is the primary potato vine desiccant in the United States, and research on alternatives is limited (Kuhar et al., 2018; Pavlista, 2001). This research indicates that glufosinate and saflufenacil are suitable alternatives to diquat for potato vine desiccation. Although these products had slower desiccation activity, ultimately, vine and leaf desiccation and subsequent effects on skin set, potato yield, and grade were similar to those on diquat. It should also be noted that carfentrazone and saflufenacil improved initial potato vine desiccation by glufosinate. Carfentrazone is more expensive than saflufenacil, and when applied alone, carfentrazone is less effective than diquat and glufosinate. Therefore, potato producers are less interested in carfentrazone than saflufenacil as a desiccant. However, carfentrazone was co-applied with glufosinate in this study to serve as a comparison treatment to glufosinate plus saflufenacil. Saflufenacil, like other PPO-inhibiting herbicides, is a good candidate for co-application with glufosinate used for potato vine 
desiccation (Boydston et al., 2018; Soltani, 2013). However, more information on saflufenacil as a potato vine desiccant is needed, especially residue studies to determine mammalian safety of the herbicide applied before potato harvest.

\section{Literature cited}

BASF. 2016. Sharpen herbicide product label. BASF, Research Triangle Park, NC.

Boydston, R.A., D.A. Navarre, H.P. Collins, and B. Chaves-Cordoba. 2018. The effect of vine kill method on vine kill, tuber skinning injury, tuber yield and size distribution, and tuber nutrients and phytonutrients in two potato cultivars grown for early potato production. Amer. J. Potato Res. 95:54-70.

Crop Data Management Systems, Inc. 2019. Label database. 20 May 2019. <http://www.cdms.net/LabelDatabase $>$.

FMC Corp. 2015. Aim herbicide product label. FMC Corp., Philadelphia, PA.

Gonnella, M., O. Ayala, A. Paradiso, V. Buono, L.D. Gara, P. Santamaria, and F. Serio. 2009. Yield and quality of early potato cultivars in relation to the use of glufosinate-ammonium as desiccant. J. Sci. Food Agr. 89:855-860.

Haderlie, L.C., J.L. Halderson, P.W. Leino, P.J. Petersen, and R.H. Callihan. 1989. Chemical desiccation of potato vines. Amer. Potato J. 66:53-62.

Ivany, J.A. and J.B. Sanderson. 2001. Response of potato (Solanum tuberosum) cultivars to glufosinate-ammonium and diquat used as desiccants. Weed Technol. 15:505-510.

Kuhar, T.P., G.C. Hamilton, M.J. VanGessel, E. Sanchez, and C.A. Wyenandt. 2018. 2018 Mid-Atlantic commercial vegetable production recommendations. Virginia Tech, Virginia State Univ., Virginia Coop Ext. Publ. 456-420.

Lulai, E.C. and P.H. Orr. 1993. Determining the feasibility of measuring genotypic differences in skin-set. Amer. Potato J. 70:599-610.

Misener, G.C. and C.F. Everett. 1981. Vine pulling as a means of top killing potatoes. Amer. Potato J. 58:103-109.

Murphy, H.J. 1968. Potato vine killing. Amer. Potato J. 45:472-478.

Mutch, D.R., D. Penner, F. Roggenbuck, and R.W. Chase. 1984. The use of additives, temperature, and plant position to increase efficacy of dinoseb for potato (Solanum tuberosum) vine desiccation. Amer. Potato J. 61:577-586.

Nolte, P. and N. Olsen. 2005. What is skin set and how do we achieve it? University of Idaho. 14 Sept. 2018. <https:// www.uidaho.edu/-/media/UIdahoResponsive/Files/cals/programs/ potatoes/Storage/Skin-set-and-howdo-we-achieve-it-05.pdf?la $=$ en \&hash $=$ 0AF70D6008D959E1093368412047 D039920CC3C2>.

Pavlista, A.D. 2001. UCC-C4243 desiccation of potato vines. Hort Technology 11:86-89.
Richardson, B. 2017. Virginia potato \& vegetable review. Virginia Dept. Agr. Consumer Serv. Richmond, VA.

Sabba, R.P. and A.J. Bussan. 2012. Comparison of skin-set and periderm maturation in 'Red Norland' potatoes grown in two soil types in Wisconsin. Amer. J. Potato Res. 89:508-511.

Soltani, N. 2013. Desiccation in dry edible beans with various herbicides. Can. J. Plant Sci. 93:871-878.

Strange, P.C. and K.W. Blackmore. 1990. Effect of whole seed tubers, cut seed and within row spacing on potato (cv. Sebago) tuber yield. Austral. J. Expt. Agr. 30:427431.

Syngenta. 2015. Reglone herbicide product label. Syngenta LLC., Greensboro, NC.

University of Maine. 2011. Vine desiccation. 5 Feb. 2019. <https://extension. umaine.edu/potatoes/wp-content/ uploads/sites/97/2010/03/Desiccants. pdf>.

U.S. Department of Agriculture. 2011. United States standards for grades of potatoes. U.S. Dept. Agr., Washington, DC.

U.S. Department of Agriculture. 2018. North American potatoes. U.S. Dept. Agr., Natl. Agr. Stat. Serv., Washington, DC.

Waterer, D., H. Elsadr, and M. McArthur. 2011. Skin color, scab sensitivity and field performance of lines derived from spontaneous chimeras of Red Norland potato. Amer. J. Potato Res. 88:199-206. 